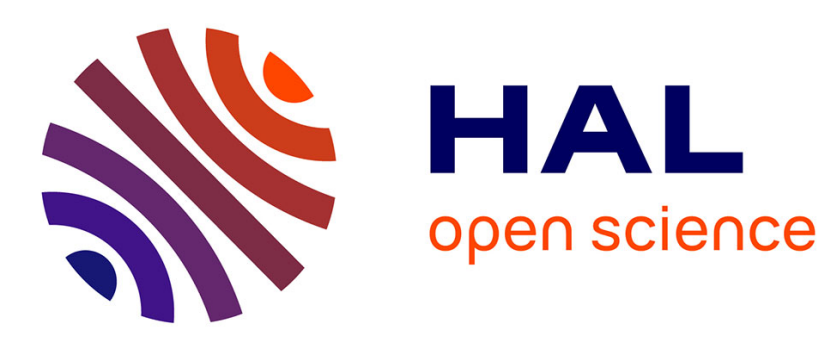

\title{
Foliar resorption in Quercus petraea subsp. iberica and Arbutus andrachne along an elevational gradient
}

Duygu Kilic, Hamdi Güray Kutbay, Tuğba Ozbucak, Rena Huseyinova

\section{To cite this version:}

Duygu Kilic, Hamdi Güray Kutbay, Tuğba Ozbucak, Rena Huseyinova. Foliar resorption in Quercus petraea subsp. iberica and Arbutus andrachne along an elevational gradient. Annals of Forest Science, 2010, 67 (2), 10.1051/forest/2009106 . hal-00883548

\section{HAL Id: hal-00883548 \\ https://hal.science/hal-00883548}

Submitted on 1 Jan 2010

HAL is a multi-disciplinary open access archive for the deposit and dissemination of scientific research documents, whether they are published or not. The documents may come from teaching and research institutions in France or abroad, or from public or private research centers.
L'archive ouverte pluridisciplinaire HAL, est destinée au dépôt et à la diffusion de documents scientifiques de niveau recherche, publiés ou non, émanant des établissements d'enseignement et de recherche français ou étrangers, des laboratoires publics ou privés. 


\title{
Foliar resorption in Quercus petraea subsp. iberica and Arbutus andrachne along an elevational gradient
}

\author{
Duygu KILIC $^{1}$, Hamdi Güray KutBaY ${ }^{1 *}$, Tuğba OzBucaK ${ }^{1,2}$, Rena HuseYINOva ${ }^{1}$ \\ ${ }^{1}$ University of Ondokuz Mayıs, Faculty of Science \& Arts, Department of Biology, 55139, Samsun, Turkey \\ ${ }^{2}$ Ordu University, Faculty of Science \& Arts, Department of Biology, Ordu, Turkey
}

Keywords:

Grime strategies /

mean residence time (MRT) /

N/P ratio /

resorption efficiency /

resorption proficiency /

sympatric species

Mots-clés :

stratégies de Grime /

temps moyenne de résidence (MRT) /

rapport N/P /

efficience de la résorption /

capacité de résorption /

espèces sympatriques

(Received 16 February 2009; accepted 8 July 2009)

\begin{abstract}
- The resorption of nutrients (mainly $\mathrm{N}$ and $\mathrm{P}$ ) from senescing leaves may be a key component of adaptive mechanisms that conserve scarce nutrients. Resorption may be expressed in two ways as resorption efficiency (RE) which is the ratio of the resorbed amounts of nutrient losses during leaf senescence in relation to its prior amount deposited in leaves and resorption proficiency (RP) is the level to which nutrient concentration per unit leaf mass is reduced in senescent leaves.

- There is still much debate whether or not different life-forms (i.e. deciduous and evergreen species) show different foliar resorption patterns. Two sympatric species, namely Quercus petraea (Mattuschka) Liebl. subsp. iberica (Steven ex Bieb.) Krassiln. (deciduous) and Arbutus andrachne L. (evergreen) along an elevational gradient were compared with each other to determine whether or not nitrogen and phosphorus resorption efficiency and proficiency varies along the elevational gradient and which leaf parameters were as related to RE and RP.

- NRE was found to be rather low in Q. petraea subsp. iberica compared to other deciduous species. Similarly, PRE in A. andrachne was rather low compared to other evergreen species. Mean residence time (MRT) measures how long a unit of nitrogen $\left(\mathrm{MRT}_{\mathrm{N}}\right)$ and phosphorus $\left(\mathrm{MRT}_{\mathrm{P}}\right)$ is present in the plant. $\mathrm{MRT}_{\mathrm{N}}$ and $\mathrm{MRT}_{\mathrm{P}}$ were found to be considerably higher in A. andrachne compared to $Q$. petraea subsp. iberica. In both species, the foliar N/P ratio was below 14 along the elevational gradient and, according to this threshold value, $\mathrm{N}$-limitation occurred in the study area. Although both species in the present study show incomplete resorption deciduous species was more proficient as compared to evergreen one due to low $\mathrm{N}$ and $\mathrm{P}$ concentrations in senescent leaves. Based on the significant correlations ( $p<0.05$ and 0.01 ) between MRT and foliar resorption, it can be concluded that MRT could interfere with the mechanisms controlling nutrient resorption.
\end{abstract}

Résumé - Résorption foliaire chez Quercus petraea subsp. iberica et Arbutus andrachne le long d'un gradient altitudinal.

- La résorption des éléments nutritifs (essentiellement $\mathrm{N}$ et $\mathrm{P}$ ) par sénescence des feuilles peut être une composante clé des mécanismes d'adaptation qui permettent de conserver les rares éléments nutritifs. La résorption peut être exprimée de deux façons : l'efficience de résorption (RE) qui est le rapport entre la quantité résorbée des pertes d'éléments nutritifs au cours de la sénescence des feuilles par rapport à son montant déposé auparavant dans les feuilles et la capacité de résorption (RP) qui est le niveau auquel la concentration des éléments nutritifs par unité de masse de feuilles est réduite dans les feuilles sénescentes.

- Il reste encore beaucoup de débat pour déterminer si les différentes formes de vie (c'est-à-dire les espèces décidues et les espèces sempervirentes) présentent différents modes de résorption foliaire. Deux espèces sympatriques, à savoir Quercus petraea (Mattuschka) Liebl. subsp. iberica (Steven ex Bieb.) Krassiln. (décidue) et Arbutus andrachne L. (sempervirente), ont été comparées l'une à l'autre, le long d'un gradient altitudinal, afin de déterminer si l'efficience de résorption de l'azote et du phosphore et la capacité de résorption varient le long d'un gradient altitudinal et quels paramètres de la feuille sont liés à RE et RP.

- NRE a été trouvé plutôt faible chez Q. petraea subsp. iberica par rapport à d'autres espèces décidues. De même, chez A. andrachne PRE a été plutôt faible par rapport à d'autres espèces

\footnotetext{
* Corresponding author: hguray@ omu.edu.tr
} 
sempervirentes. Le temps de résidence moyen (MRT) mesure combien de temps une unité d'azote $\left(\mathrm{MRT}_{\mathrm{P}}\right)$ et de phosphore $\left(\mathrm{MRT}_{\mathrm{P}}\right)$ est présente dans la plante. $\mathrm{MRT}_{\mathrm{P}}$ et $\mathrm{MRT}_{\mathrm{P}}$ étaient considérablement plus élevés chez A. andrachne par rapport à $Q$. petraea subsp. iberica. Chez les deux espèces, le ratio foliaire N/P était inférieur à 14 le long du gradient altitudinal, en fonction de la valeur de ce seuil, une limitation d'azote s'est produite dans la zone d'étude. Bien que les deux espèces, dans la présente étude, montrent une résorption incomplète, l'espèce décidue avait une meilleure capacité de résorption comparativement à l'espèce sempervirente en raison de la faible concentration de $\mathrm{N}$ et de $\mathrm{P}$ dans les feuilles sénescentes. Sur la base des corrélations significatives $(p<0.05$ et 0.01$)$ entre MRT et la résorption foliaire, il peut être conclu que MRT pourrait interférer avec les mécanismes de contrôle de la résorption des éléments nutritifs.

\section{INTRODUCTION}

Nutrient resorption is known to be one of the most important strategies employed by plants to conserve nutrients prior to senescence. The resorption of nutrients and their removal from senescent leaves, and their accumulation or storage in the perennial parts of trees is a common process. This resorption of nutrients may meet a significant demand of the nutritional requirements for the production of new biomass. Similarly, resorption is a beneficial process because the tree is less subject to losses due to a decrease in biomass decomposition (Regina and Tarazona, 2001). Nutrients which are resorbed from the plant during senescence are directly available for further plant growth, which makes a species less dependent on current nutrient uptake. Nutrients which are not resorbed, however, will be circulated through litterfall in the longer term. All of these factors have important implications for element cycling at the ecosystem level (van Heerwaarden et al., 2003).

The resorption of nutrients (mainly $\mathrm{N}$ and $\mathrm{P}$ ) from senescing leaves may be a key component of adaptive mechanisms that conserve scarce nutrients (Niinemets and Tamm, 2005; Killingbeck, 1996).

Resorption can be expressed in two ways: as resorption efficiency and resorption proficiency. Resorption efficiency is most accurately calculated for any nutrient as the area-specific mass in green leaves minus the area-specific mass in senesced leaves divided by the area-specific mass in green leaves

\section{[(Nutrient in live leaves - Nutrient in senescent leaves)/}

$$
\text { Nutrient in live leaves }] \times 100 \text {. }
$$

A new measure of resorption was introduced by Killingbeck (1996) as resorption proficiency. Killingbeck (1996) emphasized that resorption proficiency (the concentration of a nutrient in senesced leaves) over resorption efficiency is not subject to temporal variation in nutrient concentration in green leaves or the timing of sampling. Proficiency is simply the amount of a nutrient that remains in fully senesced leaves (Yuan et al., 2005a).

Two sympatric species along an elevational gradient were selected for this study. One of these species is deciduous (Quercus petraea subsp. iberica; deciduous), while the other is an evergreen species (Arbutus andrachne). Soil fertility and soil water content vary along the elevational gradient. Both species are canopy species and occurred along the elevational gradient. The present study addresses three main objectives: (a) to determine which leaf parameters were related to nitrogen and phosphorus efficiency (NRE and PRE) and proficiency (NRP and PRP); (b) to compare deciduous and evergreen species in terms of resorption efficiency and proficiency, leaf mass per area (LMA); and (c) to determine whether or not nitrogen and phosphorus resorption efficiency and proficiency varies along the elevational gradient in two sympatric species.

\section{MATERIALS AND METHODS}

\subsection{Study Area and Collection of Samples}

This study was carried out along an elevational gradient in Amasya, Yassical Mountain (1148 m a s 1), situated in the North of Turkey, where both species are widespread. Plots of $20 \mathrm{~m} \times 20 \mathrm{~m}$ $\left(400 \mathrm{~m}^{2}\right)$ were chosen at low $(450 \mathrm{~m}$ a s l), middle $(600 \mathrm{~m}$ a s 1$)$ and high (800 $\mathrm{m} \mathrm{a} \mathrm{s} 1)$ altitudes from homogeneous places. Plots were chosen which had closed tree canopies. Chestnut soils which formed as a result of calcification were dominant along the catena (Turkish Ministry of Agriculture and Forestry, 1991). Average annual rainfall ranges from $24.2 \mathrm{~mm}$ (September) to $86.9 \mathrm{~mm}$ (June). January is the coldest month $\left(0.9^{\circ} \mathrm{C}\right)$ and July $\left(21.3^{\circ} \mathrm{C}\right)$ is the hottest month. The climate of the study area has a transitional character between semiarid and humid Mediterranean climates (Turkish Ministry of Agriculture, 2002).

Van Heerwaarden et al. (2003) proposed that current measures of nutrient resorption efficiency lead to a substantial underestimation of the real resorption efficiency, due to changes in leaf mass or leaf area during senescence. These authors suggested pre-selection of leaves in order to minimize the risk of comparing green and senescent leaves of different cohorts (Rentería et al., 2005). Ten trees for each species were pre-selected and marked. Leaf samples from throughout the midcrown of each individual were taken and consisted of leaves with no evidence of insect attack. Individuals were selected $\geq 2.5 \mathrm{~m}$. from the stems of neighboring canopy trees to avoid potential microsite variation (Boerner and Koslowsky, 1989). Senesced leaves were obtained from near the marked trees. Fifteen to twenty leaf samples were taken from each individual for both species and each altitude at each sampling date.

Green leaf samples of $Q$. petraea subsp. iberica were sampled in mid-June, whilst senesced leaf samples were collected in October. Green leaves of A. andrachne were sampled in mid-April, while senesced leaf samples were collected in June. Foliar nutrient concentrations are most stable in mid-June and mid-April in deciduous and evergreen species, respectively (Fig. 1). When fully senesced, leaves 

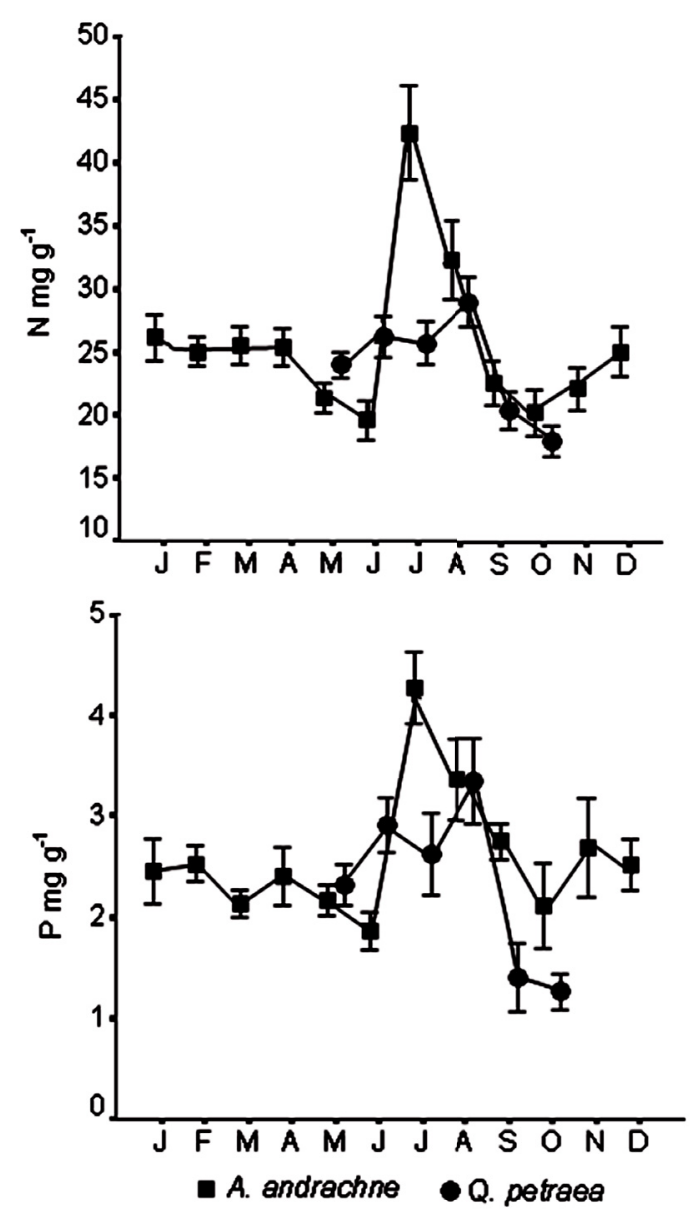

Figure 1. Nitrogen and phosphorus dynamics across time for the two studied species.

of $Q$. petraea subsp. iberica become light brown and dry, and those of $A$. andrachne become yellow and readily fall off when touched. Resorption efficiency (\%) was calculated as the percentage of $\mathrm{N}, \mathrm{P}$ and recovered from senescing leaves (Rejmánková, 2005):

- Leaf samples of both species were scanned and the leaf area was calculated by using Net Cad software (Anonymous, 1999). Leaf samples of both species were oven dried at $70{ }^{\circ} \mathrm{C}$ until they reached a constant weight, and then weighed.

- Leaf mass per area (LMA) of fully expanded leaves and senescence leaves was calculated from dry leaf mass (oven-dried $48 \mathrm{~h}$ at $\left.60{ }^{\circ} \mathrm{C}\right)$. Grime's CSR (C: competitive; S: stress-tolerant; R: ruderal) strategies were used to compare both sympatric species in terms of $\mathrm{N}$ and $\mathrm{P}$ usage strategies by using a program developed in Microsoft Excel. Canopy height, dry matter content, flowering period, the onset of flowering, lateral spreading, dry leaf weight and specific leaf area were used to determine which Grime's category the studied species belonged (Hodgson et al., 1999).

The mean residence time (MRT, years) of a unit of $\mathrm{N}\left(\mathrm{MRT}_{\mathrm{N}}\right)$ and $\mathrm{P}$ $\left(\mathrm{MRT}_{\mathrm{P}}\right)$ in the leaf was estimated as MRT $=$ leaf life $\operatorname{span} \times 1 /(1-r)$ where $r$ is the nutrient resorption efficiency and leaf life span is expressed in years (Aerts and Chapin, 2000).
Table I. The comparison of two sympatric species regarding leaf traits by one-way ANOVA.

\begin{tabular}{lccc}
\hline Leaf trait & $\mathrm{d} f$ & $F$-value & $p$ \\
\hline $\mathrm{N} \mathrm{mg} / \mathrm{g}$ & 647 & 113.12 & $0.001 * *$ \\
$\mathrm{P} \mathrm{mg} / \mathrm{g}$ & 647 & 64.36 & $0.003 * *$ \\
LMA mg/dm & 647 & 242.23 & $0.001 * *$ \\
$\mathrm{~N} / \mathrm{P}$ & 647 & 1.028 & $0.141 \mathrm{NS}$ \\
$\mathrm{NRE}$ & 647 & 36.29 & $0.003 * *$ \\
$\mathrm{PRE}$ & 647 & 3.28 & $0.162 \mathrm{NS}$ \\
$\mathrm{NRP}$ & 647 & 9.40 & $0.006 * *$ \\
$\mathrm{PRP}$ & 647 & 17.60 & $0.004 * *$ \\
$\mathrm{MRT}_{\mathrm{N}}$ & 647 & 109.63 & $0.001 * *$ \\
$\mathrm{MRT}_{\mathrm{P}}$ & 647 & 30.08 & $0.003 * *$ \\
\hline
\end{tabular}

NS: Not significant; $\mathrm{d} f$ : degrees of freedom; $* * p<0.01$.

\subsection{Chemical analyses}

Leaf samples were digested in a mixture of nitric and perchloric acids, with the exception of samples for $\mathrm{N}$ analysis. Nitrogen was determined by the micro Kjeldahl method with a Kjeltec Auto 1030 Analyzer (Tecator, Sweden) after digesting the samples in concentrated $\mathrm{H}_{2} \mathrm{SO}_{4}$ with a selenium catalyst. $\mathrm{P}$ was determined with the stannous chloride method using a Jenway spectrophotometer (Allen et al. 1986).

Five soil samples of 0-60 cm depth were collected using an auger at each elevation and each sampling date. The soil samples were airdried and then sieved to pass through a $2-\mathrm{mm}$ screen. The $\mathrm{pH}$ values were measured in deionized water $(1: 1)$. Soil nitrogen $(\mathrm{g} / \mathrm{kg})$ was determined by the micro Kjeldahl method. Soil phosphorus $(\mathrm{g} / \mathrm{kg})$ was determined spectrophotometrically following extraction by ammonium acetate. Organic matter $(\mathrm{g} / \mathrm{kg})$ concentration was determined using the Walkley-Black method (Allen et al., 1986). For the determination of soil moisture $\left(\mathrm{cm}^{3} \mathrm{H}_{2} \mathrm{O} / 100 \mathrm{~cm}^{3}\right.$ soil), samples of approximately 250-300 g were placed in soil pins, weighed fresh, dried at $105^{\circ} \mathrm{C}$ for $48 \mathrm{~h}$, then weighed dry; Soil moisture was then calculated on a volume basis (Boerner 1984). Soil nutrient concentrations were determined according to Allen et al. (1986).

Taxonomic nomenclature for plant species followed that of Brummitt and Powell (1992).

\subsection{Statistical analyses}

One and two-way analysis of variance (ANOVA) and a multivariate General Linear Models procedure were carried out using SPSS Version 10.0 (Anonymous 1999). Dependent and independent variables were foliar nutrient concentrations and foliar resorption, and species, growth period and localities, respectively. Following analysis of variance, Tukey's honestly significant difference (HSD) test was used to rank means. Pearson correlation coefficients among leaf and soil traits were also calculated.

\section{RESULTS}

Annual changes in $\mathrm{N}$ and $\mathrm{P}$ concentrations were similar in both species (Fig. 1). There were statistically significant differences between the two sympatric species regarding leaf traits, except for N/P ratio and PRE (Tab. I). Leaf $\mathrm{N}$ concentration 
in both species was different at $600 \mathrm{~m}$ compared with $450 \mathrm{~m}$ and $800 \mathrm{~m}$ respectively. Similarly, leaf $\mathrm{P}$ concentration was significantly different at $800 \mathrm{~m}$ in both species (Tab. II). No significant differences were found in A. andrachne along the elevational gradient in terms of $\mathrm{N} / \mathrm{P}$ ratio. However, $\mathrm{N} / \mathrm{P}$ ratio at $800 \mathrm{~m}$ was significantly different along the elevational gradient in $Q$. petraea subsp. iberica. N/P ratio in $Q$. petraea subsp. iberica was higher than that of $A$. andrachne and ranged from 10.10-11.61. N/P ratio varied between 8.00-12.00 in $A$. andrachne. LMA values were significantly different along the elevational gradient in both species $(p<0.01)$ and higher in $A$. andrachne. Similarly $\mathrm{MRT}_{\mathrm{N}}$ and $\mathrm{MRT}_{\mathrm{P}}$ in $A$. andrachne were also considerably higher than those of $Q$. petraea subsp. iberica. $\mathrm{MRT}_{\mathrm{N}}$ and $\mathrm{MRT}_{\mathrm{P}}$ did not significantly change along the elevational gradient except for $\mathrm{MRT}_{\mathrm{N}}$ in $A$. andrachne, which varied significantly along the elevational gradient (Tab. II).

P concentrations and NRP varied significantly along the elevational gradient in $Q$. petraea subsp. iberica $(p<0.01)$. However, N concentrations, NRE, PRE and PRP were not significantly changed in either species. (Tab. II).

Significant correlations $(p<0.01)$ were found between green leaf $\mathrm{N}$ concentrations and NRE and PRE in both species. There were negative correlations between NRP and NRE and also between PRE and PRP, respectively in both species. Statistically significant correlations $(p<0.01)$ were also found between $\mathrm{MRT}_{\mathrm{N}}$ and NRE and also between MRT $\mathrm{P}$ and PRE, respectively. However, NRP and PRP were negatively correlated with $\mathrm{MRT}_{\mathrm{N}}$ and $\mathrm{MRT}_{\mathrm{P}}$ in both species (Tabs. III and IV).

Both soil nitrogen and organic matter concentrations were at medium level, whereas soil phosphorus concentrations were rather low. Total nitrogen, available phosphorus, soil water content and soil organic matter increased along the elevational gradient. However, soil $\mathrm{pH}$ decreased along the elevational gradient (Tab. V).

\section{DISCUSSION}

NRE was found to be higher in A. andrachne, whereas PRE was higher in $Q$. petraea subsp. iberica. Huang et al. (2007) found that PRE was lower in evergreen species than deciduous species. The negative effect of this low resorption efficiency is outweighed by the positive effect of increased leaf longevity on mean residence time (Escudero et al., 1992). $\mathrm{MRT}_{\mathrm{N}}$ and $\mathrm{MRT}_{\mathrm{P}}$ were found to be considerably higher in A. andrachne compared to $Q$. petraea subsp. iberica. Long leaf lifespan prolonged $\mathrm{MRT}_{\mathrm{N}}$ and $\mathrm{MRT}_{\mathrm{P}}$ by increasing the retention time of $\mathrm{N}$ and $\mathrm{P}$ (Silla and Escudero, 2004). $\mathrm{MRT}_{\mathrm{N}}$ and $\mathrm{MRT}_{\mathrm{P}}$ were significantly correlated with NRE and PRE, respectively in deciduous species. Similarly, MRT was significantly correlated with PRE in evergreen species. Plants with low LMA have leaves with a short lifespan and high nitrogen concentration and this relationship would be important in mixed species stands containing species differing in leaf longevity (Wright and Westoby, 2003). It can be argued that such a relationship was not completely the case in the two studied species, because the leaf lifespan in $Q$. petraea subsp. iberica and $A$. andrachne were found to be 180 and $420 \mathrm{~d}$, respectively. Deciduous species has low LMA, whereas it had low leaf nitrogen concentrations than that of the evergreen one. It has been concluded that LMA varies over about two orders of magnitude across the species, and this variation is thought to represent a key trade-off between the performance and persistence of leaves. Reduction of LMA also brings potential short-term advantages of lower leaf construction costs per area, and lower maintenance costs (i.e. respiration rates per area) (Lusk et al., 2008).

Some researchers reported a positive correlation between NRE and green-leaf nutrient concentrations (del Arco et al., 1991; Escudero et al., 1992), while other researchers stated that such a relationship was not found between NRE and green-leaf nutrient concentrations (Huang et al., 2007; Niinemets and Tamm, 2005; Yuan et al., 2005a). Ratnam et al. (2008) stated that both NRE and PRE decreased as nutrient concentrations in green leaves increased. However, significant correlations were found among green-leaf $\mathrm{N}$ and $\mathrm{P}$ concentrations and NRE and PRE, respectively in both species although no significant correlations were exist among NRE, PRE and $\mathrm{N} / \mathrm{P}$ ratio. Ratnam et al. (2008) also emphasized that specific patterns of resorption and the functional relationships between nutrient concentrations in green and senesced leaves varied depending on the nutrient and plant life form.

PRE in $Q$. petraea subsp. iberica was similar to that of other deciduous species. However, NRE was found to be rather low compared to other deciduous species (Tab. VI). Norby et al. (2000) found low resorption efficiency values in Quercus alba and NRE was much lower than that of Acer sp. According to Norby et al. (2000), this may have been related to high levels of phenolic compounds in Quercus sp. Phenolic compounds can bind proteins and interfere with their hydrolysis into smaller, mobile compounds (Pugnaire and Chapin, 1993). NRE in A. andrachne were similar to those of other evergreen species. However, PRE was found to be $39.2 \%$, which is rather low compared to other evergreen species (Tab. VI).

PRE in $Q$. petraea subsp. iberica was similar to those of other deciduous species. However, NRE was found to be rather low compared to other deciduous species. NRE in A. andrachne was similar to that of other evergreen species. However, PRE was found to $39.2 \%$, which is was rather low compared to other evergreen species (Tab. VI). Several researchers (Aerts and Chapin, 2000; Huang et al., 2007) concluded that nutrient resorption efficiency did not differ among growthforms (e.g. deciduous versus evergreen species). However, statistically significant differences $(p<0.01)$ were found regarding NRE between the studied sympatric species. Significant negative correlations $(p<0.01)$ between NRE and NRP and PRE and PRP, respectively were found in both species, indicating that resorption efficiency was controlled by nutrient concentration in senescent leaves (NRP and PRP), and was distinct from leaf longevity, which leads to resource conservation (Haddad et al., 2004).

The N/P ratio of green leaves is considered as an important indication of nutrient availability (Güsewell, 2005). A foliar $\mathrm{N} / \mathrm{P}$ ratio below 14 indicated $\mathrm{N}$ limitation and foliar $\mathrm{N} / \mathrm{P}$ ratio below 12.5 indicated an optimal $\mathrm{P}$ nutrition (Aerts and Chapin 2000). The N/P ratio in $Q$. petraea subsp. iberica was found to be slightly higher than that of $A$. andrachne and ranged from 


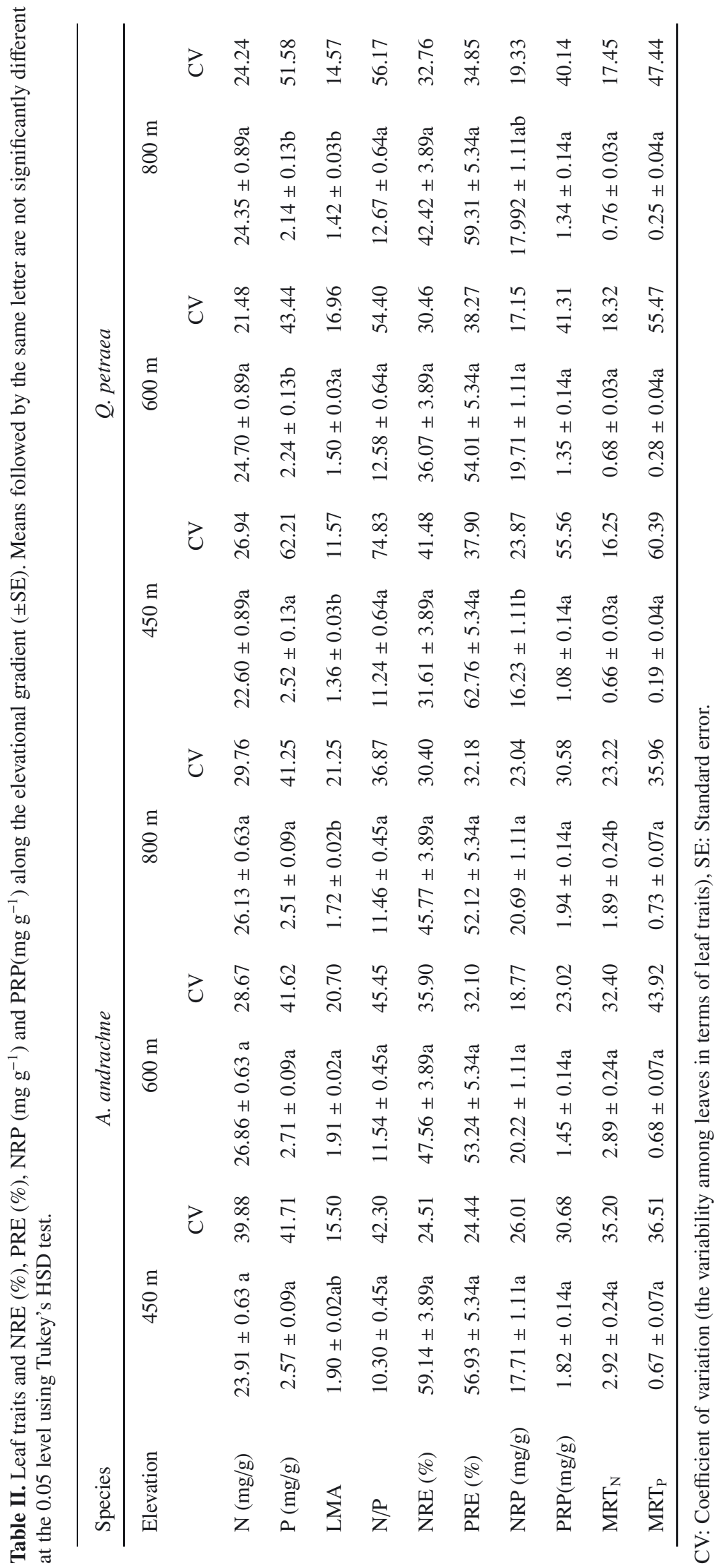


Table III. Pearson correlations among leaf traits in $Q$. petraea subsp. iberica.

\begin{tabular}{|c|c|c|c|c|c|c|c|c|c|c|c|c|}
\hline & $\mathrm{N} / \mathrm{P}$ & NRE & PRE & NRP & PRP & $\begin{array}{l}\text { Green } \\
\text { leaf N }\end{array}$ & $\begin{array}{l}\text { Green } \\
\text { leaf } P\end{array}$ & $\begin{array}{c}\text { Green } \\
\text { leaf LMA }\end{array}$ & $\begin{array}{c}\text { Senescence } \\
\text { leaf LMA }\end{array}$ & $\mathrm{MRT}_{\mathrm{N}}$ & $\mathrm{MRT}_{\mathrm{P}}$ & $\begin{array}{c}\text { Leaf } \\
\text { longevity }\end{array}$ \\
\hline$\overline{\mathrm{N} / \mathrm{P}}$ & - & & & & & & & & & & & \\
\hline NRE & 0.15 & - & & & & & & & & & & \\
\hline PRE & 0.16 & $0.36^{*}$ & - & & & & & & & & & \\
\hline NRP & -0.04 & $-0.89 * *$ & -0.28 & - & & & & & & & & \\
\hline PRP & $-0.49 * *$ & -0.20 & $-0.70 * *$ & 0.19 & - & & & & & & & \\
\hline Green leaf N & 0.29 & $0.43 * *$ & 0.21 & 0.02 & -0.07 & - & & & & & & \\
\hline Green leaf $\mathrm{P}$ & $-0.49 * *$ & 0.24 & $0.38 *$ & -0.21 & 0.29 & 0.08 & - & & & & & \\
\hline Green leaf LMA & -0.01 & -0.04 & 0.13 & -0.01 & 0.05 & -0.08 & 0.19 & - & & & & \\
\hline Senescence leaf LMA & -0.02 & -0.29 & 0.01 & 0.31 & 0.16 & -0.02 & 0.20 & 0.16 & - & & & \\
\hline $\mathrm{MRT}_{\mathrm{N}}$ & 0.16 & $0.98 * *$ & $0.36^{*}$ & $-0.89 * *$ & -0.20 & $0.40 *$ & 0.24 & -0.01 & -0.26 & - & & \\
\hline $\mathrm{MRT}_{\mathrm{P}}$ & 0.18 & $0.50 * *$ & $0.67 * *$ & $-0.48 * *$ & $-0.47 * *$ & 0.13 & $0.38^{*}$ & 0.20 & -0.08 & $0.51 * *$ & - & \\
\hline Leaf longevity & 0.17 & 0.18 & 0.22 & -0.13 & 0.04 & 0.14 & 0.22 & -0.15 & 0.01 & 0.20 & 0.28 & - \\
\hline
\end{tabular}

$* p<0.05 ; * * p<0.01$.

Table IV. Pearson correlations among leaf traits in A. andrachne.

\begin{tabular}{|c|c|c|c|c|c|c|c|c|c|c|c|c|}
\hline & $\mathrm{N} / \mathrm{P}$ & NRE & PRE & NRP & PRP & $\begin{array}{l}\text { Green } \\
\text { leaf } N\end{array}$ & $\begin{array}{l}\text { Green } \\
\text { leaf P }\end{array}$ & $\begin{array}{c}\text { Green } \\
\text { leaf LMA }\end{array}$ & $\begin{array}{l}\text { Senescence } \\
\text { leaf LMA }\end{array}$ & $\mathrm{MRT}_{\mathrm{N}}$ & $\mathrm{MRT}_{\mathrm{P}}$ & $\begin{array}{c}\text { Leaf } \\
\text { longevity }\end{array}$ \\
\hline $\mathrm{N} / \mathrm{P}$ & - & & & & & & & & & & & \\
\hline NRE & 0.08 & & & & & & & & & & & \\
\hline PRE & 0.23 & - & & & & & & & & & & \\
\hline NRP & 0.22 & $-0.72 * *$ & 0.17 & & & & & & & & & \\
\hline PRP & -0.30 & 0.05 & $-0.58 * *$ & 0.03 & - & & & & & & & \\
\hline Green leaf $\mathrm{N}$ & 0.20 & $0.68 * *$ & 0.23 & -0.02 & 0.15 & - & & & & & & \\
\hline Green leaf P & -0.05 & 0.18 & $0.65 * *$ & 0.10 & 0.14 & $0.45^{* *}$ & & & & & & \\
\hline Green leaf LMA & -0.05 & $0.53 * *$ & 0.31 & -0.07 & 0.16 & $0.76 * *$ & $0.57 * *$ & - & & & & \\
\hline Senescence leaf LMA & -0.02 & -0.01 & -0.19 & -0.03 & 0.17 & -0.06 & -0.08 & -0.15 & - & & & \\
\hline $\mathrm{MRT}_{\mathrm{N}}$ & 0.04 & $0.94 * *$ & -0.01 & $-0.72 * *$ & 0.06 & $0.64 * *$ & 0.16 & $0.48 * *$ & -0.01 & - & & \\
\hline $\mathrm{MRT}_{\mathrm{P}}$ & 0.19 & 0.13 & $0.91 * *$ & 0.04 & $-0.58 * *$ & 0.26 & $0.69 * *$ & $0.33 *$ & -0.27 & 0.10 & - & \\
\hline Leaf longevity. & 0.20 & 0.14 & -0.03 & 0.07 & 0.13 & 0.26 & 0.19 & 0.02 & $0.36 *$ & 0.15 & 0.03 & - \\
\hline
\end{tabular}

$* p<0.05 ; * * p<0.01$.

Table V. Soil traits along the elevational gradient $( \pm$ SE). Means followed by the same letter are not significantly different at the 0.05 level using Tukey's HSD test.

\begin{tabular}{lccc}
\hline Elevation & $450 \mathrm{~m}$ & $600 \mathrm{~m}$ & $800 \mathrm{~m}$ \\
\hline Total nitrogen $(\%)$ & $0.17 \pm 0.01 a$ & $0.19 \pm 0.01 a$ & $0.23 \pm 0.01 a$ \\
Available phosphorus (ppm) & $10.15 \pm 0.96 a$ & $11.15 \pm 0.96 a$ & $13.96 \pm 0.96 a$ \\
Soil water content (\%) & $42.08 \pm 2.16 b$ & $63.00 \pm 2.16 a$ & $63.83 \pm 2.16 a$ \\
Soil organic matter (\%) & $0.96 \pm 0.18 b$ & $3.26 \pm 0.18 a$ & $3.73 \pm 1.18 a$ \\
pH & $7.96 \pm 0.03 a$ & $7.80 \pm 0.03 a b$ & $7.64 \pm 0.03 a$ \\
\hline
\end{tabular}

9.53-11.49, whereas the $\mathrm{N} / \mathrm{P}$ ratio varied between 9.46 and 10.55 in $A$. andrachne. In both species, the foliar N/P ratio was below 14 along the elevational gradient and, according to this threshold value, N-limitation occurred in the study area. Plants with low leaf-nutrient concentrations tend to minimize nutrient loss through leaf shedding and are good examples of stresstolerators (Milla et al., 2005). Güsewell (2005) stated that CS species which have low $\mathrm{P}$ concentration and high $\mathrm{N} / \mathrm{P}$ ratios partly reflect slow growth, and partly their efficient internal cycling of P. $Q$. petraea subsp. iberica has low leaf $\mathrm{P}$ concentration and belongs to the $\mathrm{C} / \mathrm{CS}$ (competitor/competitor stresstolerant) transitional type strategy, whilst $A$. andrachne has high leaf $\mathrm{P}$ concentration, and belongs to the $\mathrm{C}$ (competitor) strategy. However, there were no statistically significant differences between the two sympatric species regarding N/P ratio, although the N/P ratio is slightly higher in deciduous species. NRE and PRE are poorly predicted by foliar N/P ratios. However, this is in contrast to NRP and PRP, which appear to be 
Table VI. N and P resorption efficiency values in some deciduous and evergreen species.

\begin{tabular}{|c|c|c|c|c|}
\hline Species & Leaf habit & $\mathrm{N} \%$ & $\mathrm{P} \%$ & Source \\
\hline $\begin{array}{l}\text { Quercus petraea (Mattuschka) Liebl. subsp. } \\
\text { iberica (Steven ex Bieb.) Krassiln. }\end{array}$ & Deciduous & 27.9 & 50.4 & Present study \\
\hline Quercus prinus L. & Deciduous & 49.2 & 44.5 & Boerner (1984) \\
\hline Quercus ilicifolia Wang. & Deciduous & 70.0 & 59.1 & Killingbeck and Costigan.(1988) \\
\hline Quercus pyrenaica Willd. & Deciduous & 46.4 & - & Escudero et al. (1992) \\
\hline Betula pubescens Ehrh. & Deciduous & 69.2 & - & Escudero et al. (1992) \\
\hline Populus nigra $\mathrm{L}$. & Deciduous & 62.6 & - & Escudero et al. (1992) \\
\hline Frangula alnus P. Mill. & Deciduous & 61.6 & - & Escudero et al. (1992) \\
\hline Sambucus nigra $\mathrm{L}$. & Deciduous & 49.6 & - & Escudero et al. (1992) \\
\hline Fraxinus angustifolia Vahl & Deciduous & 39.7 & - & Escudero et al. (1992) \\
\hline Acer rubrum $\mathrm{L}$. & Deciduous & 65.0 & 74.0 & Côté et al. (2002) \\
\hline Populus grandidentata Michx. & Deciduous & 56.0 & 65.2 & Côté et al. (2002) \\
\hline Fagus grandifolia Ehrh. & Deciduous & 62.0 & 77.5 & Côté et al. (2002) \\
\hline Fagus orientalis Lipsky & Deciduous & 73.4 & 72.9 & Kutbay et al. (2003) \\
\hline Rhododendron luteum Sweet & Deciduous & 55.8 & 79.7 & Kutbay et al. (2003) \\
\hline Hypericum androsaemum $\mathrm{L}$. & Deciduous & 44.1 & 50.8 & Kutbay et al.(2003) \\
\hline Vaccinium arctostaphylos L. & Deciduous & 28.5 & 51.7 & Kutbay et al. (2003) \\
\hline Quercus faginea Lam. & Deciduous & 45.0 & 43.0 & Mediavilla and Escudero (2003) \\
\hline Quercus pyrenaica Willd. & Deciduous & 47.0 & 51.0 & Mediavilla and Escudero (2003) \\
\hline MEAN & DECIDUOUS & $50.77 \pm 14.39$ & $59.55 \pm 12.29$ & \\
\hline Quercus suber L. & Evergreen & 47.9 & - & Escudero et al. (1992) \\
\hline Quercus suber L. & Evergreen & 49.0 & 55.9 & Mediavilla and Escudero (2003) \\
\hline Quercus coccifera $\mathrm{L}$. & Evergreen & 32.0 & 42.9 & Mediavilla and Escudero (2003) \\
\hline Quercus rotundifolia Lam. & Evergreen & 31.0 & 33.2 & Mediavilla and Escudero (2003) \\
\hline MEAN & EVERGREEN & $39.33 \pm 10.15$ & $43.01 \pm 11.58$ & \\
\hline
\end{tabular}

more responsive to N/P ratios (Ratnam et al., 2008). Only PRP was negatively correlated with N/P ratio in deciduous species and the other correlations among $\mathrm{RE}$ and $\mathrm{RP}$ and $\mathrm{N} / \mathrm{P}$ ratio were not significant in the present study (Tabs. III and IV).

Killingbeck (1996) stated that resorption is highly proficient in plants that have reduced nitrogen and phosphorus during their senescent stages to concentrations below $7 \mathrm{mg} \mathrm{g}^{-1}$ and $0.5 \mathrm{mg} \mathrm{g}^{-1}$, respectively. Both species in the present study show incomplete resorption according to threshold values defined by Killingbeck (1996). Huang et al. (2007) found that $\mathrm{N}$ concentration in senesced leaves was lower in species with longer leaf lifespan. High resorption proficiency implies low concentrations because a low $\mathrm{N}$ concentration in senesced parts is the evidence of high proficiency, and vice versa (Yuan et al., 2005a). Deciduous species was more proficient because low $\mathrm{N}$ concentrations were found in senescent leaves.

In summary, based on the significant correlations between MRT and foliar resorption, it can be concluded that MRT could interfere with the mechanisms controlling nutrient resorption. Deciduous species was more proficient as compared to evergreen one due to low $\mathrm{N}$ and $\mathrm{P}$ concentrations in senescent leaves. 


\section{REFERENCES}

Aerts R. and Chapin F.S. III., 2000. The mineral nutrition of wild plants revisited: a re-evolution of processes and patterns. Adv. Ecol. Res. 30: $1-67$.

Allen S.E., Grimshaw H.M., Parkinson J.A., Quarmby C., and Roberts J.D., 1986. Chemical analysis. In: Chapman SB (Ed.), Methods in Plant Ecology, Blackwell Science, Oxford, pp. 411-466.

Anonymous., 1999. SPSS 10.0 for Windows. SPSS Inc., New York.

Anonymous., 1999. Net Cad for Windows Version $2.090 \mathrm{~b} 56$.

Boerner R.E.J., 1984. Foliar nutrient dynamics, growth and nutrient use efficiency of Hamamelis virginiana in three forest microsites. Can. J. Bot. 63: 1476-1481.

Boerner R.E.J. and Koslowsky S.D., 1989. Microsite variations in soil chemistry and nitrogen mineralization in a beech-maple forest. Soil Biol. Biochem. 21: 795-801.

Brummitt R.K. and Powell C.E., 1992. Authors of Plant Names. Royal Botanic Gardens, Kew Edinburgh, 733 p.

Côté B., Fyles J.W., and Djalilvand H., 2002. Increasing N and P resorption efficiency and proficiency in northern deciduous hardwoods with decreasing foliar N and P concentrations. Ann. For. Sci. 59: 275-281.

Del Arco J.M., Escudero A., and Garrido M.V., 1991. Effects of site characteristics on nitrogen retranslocation from senescing leaves. Ecology 72: 701-708.

Escudero A., del Arco J.M., and Garrido M.V., 1992. The efficiency of nitrogen retranslocation from leaf biomass in Quercus ilex ecosystems. Vegetatio 99-100: 225-237.

Güsewell S., 2004. N/P ratios in terrestrial plants: variation and functional significance. New Phytol. 164: 243-266.

Haddad C.R.B., Lemos D.P., and Mazzafera P., 2004. Leaf life span and nitrogen in semideciduous forest tree species (Croton priscus and Hymenaea courbaril). Sci. Agricol. 61: 462-465.

Hodgson J.G., Wilson P.S., Hunt R., Grime J.P., and Thompson K., 1999. Allocating C-S-R plant functional types; a soft approach to a hard problem. Oikos 85: 282-294.

Huang J., Wang X., and Yan E., 2007. Leaf nutrient concentration, nutrient resorption and litter decomposition in an evergreen broad-leaved forest in eastern China. For Ecol. Manage. 239: 150-158.

Killingbeck K.T. and Costigan S.A., 1988. Element resorption in a guild of understory shrub species: niche differentiation and resorption thresholds. Oikos 53: 366-374.

Killingbeck K.T., 1996. Nutrients in senesced leaves: keys to the search for potential resorption and resorption proficiency. Ecology 77: $1716-1727$.

Kutbay H.G., Yalcın E., and Bilgin A., 2003. Foliar N and P resorption and foliar nutrient concentrations in canopy and subcanopy of a Fagus orientalis Lipsky forest. Belg. J. Bot. 136: 35-44.
Lusk C.H., Reich P.B., Montgomery R.A., Eckerly D.A., and CavenderBares J. 2008. Why are evergreen leaves so contrary about shade? Trends Ecol. Evol. 23: 299-303.

Mediavilla S. and Escudero A., 2003. Leaf life span differs from retention time of biomass and nutrients in the crowns of evergreen species. Funct. Ecol. 17: 541-548.

Milla R., Castro-Díez P., Maestro-Martínez M., and Montserrat-Martí G., 2005. Does the gradualness of leaf shedding govern nutrient resorption from senescing leaves in Mediterranean woody plants? Plant Soil 278: 303-313.

Niinemets U. and Tamm U., 2005. Species differences in timing of leaf fall and foliage chemistry modify nutrient resorption efficiency in deciduous temperate forest stands. Tree Physiol. 25: 1001-1014.

Norby R.J., Long T.M., Hartz-Rubin J.S., and O'Neill E.G., 2000. Nitrogen resorption in senescing tree leaves in a warmer $\mathrm{CO}_{2}$ enriched atmosphere. Plant Soil 224: 15-29.

Pugnaire F.I. and Chapin F.S. III., 1993. Controls over nutrient resorption from leaves of evergreen Mediterranean species. Ecology 74: 124-129.

Ratnam J., Sankaran M., Hanan N.P., Grant R.C., and Zambatis N., 2008. Nutrient resorption patterns of plant functional groups in a tropical savanna: variation and functional significance. Oecologia 157: 141-151.

Regina I.S. and Tarazona T., 2001. Nutrient cycling in a natural beech forest and adjacent planted pine in northern Spain. Forestry 74: 11-28.

Rejmánková E., 2005. Nutrient reorption in wetland macrophytes: comparison across several regions of different nutrient status. New Phytol. 167: 471-482.

Rentería L.Y., Jaramillo V.J., Martínez-Yrízar A., and Pérez-Jiménez A., 2005. Nitrogen and phosphorus resorpion in trees of a Mexican tropical dry forest. Trees 19: 431-441.

Silla F. and Escudero A., 2004. Nitrogen-use efficiency: trade-offs between $\mathrm{N}$ productivity and mean residence time at organ, plant and population levels. Funct. Ecol. 18: 511-521.

Turkish Ministry of Agriculture and Forestry, 1991. Amasya City Landscape Features, Department of Rural Affairs, Ankara, 333 p.

Turkish Ministry of Agriculture 2002. Meteorological Bulletin, Mean and Extreme Temperature and Precipitation Values State Meteorological Service, Ankara, 675 p.

Van Heerwaarden L.M., Toet S. and Aerts R., 2003. Current measures of nutrient resorption efficiency lead to a substantial underestimation of real resorption efficiency: facts and solutions. Oikos 101: 664-669.

Wright I.J. and Westoby M., 2003. Nutrient concentration, resorption and lifespan: leaf traits of Australian sclerophyll species. Funct. Ecol. 17: $10-19$.

Yuan Z.Y., Li L.H., Han X.G., Huang J.H., Jiang G.M., and Wan S.Q., 2005a. Soil characteristics and nutrient resorption in Salix krylovii native to northern China. Plant Soil 273: 257-268. 